\title{
СТРУКТУРНА РЕОРГАНІЗАЦІЯ ПЕЧІНКИ, СПРИЧИНЕНА МЕЛФАЛАНОМ, ТА ПРИ КОРЕКЦІЇ ПРЕПАРАТАМИ ГРАНУЛОЦИТАРНОГО КОЛОНІЕСТИМУЛЮЮЧОГО ФАКТОРА I ЕНТЕРОСОРБЦІЄЮ
}

\section{Тернопільський національний медичний університет імені І. Я. Горбачевського МОз України}

РЕзЮМЕ. Мета роботи - дослідити структурні зміни печінки на тлі введення мелфалану та препаратів гранулоцитарного колонієстимулюючого фактора (Г-КСФ) і ентеросорбції.

Матеріал і методи. Проведено дослідження структурної реорганізації тканини печінки в експерименті на 60 статевозрілих білих щурах при застосуванні мелфалану, філграстиму і рГ-КСФ та ентеросорбції з сорбентом С2

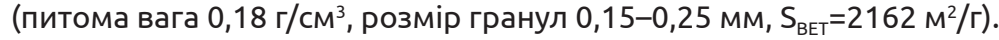

Результати. Встановлено, що лише при поєднанні препаратів Г-КСФ та курсу ентеральної сорбційної терапії спостерігалося максимальне відновлення гістоструктури печінки, яка порушується на тлі введення цитостатика мелфалану.

Висновки. Отримані нами результати слугують основою для подальшого вивчення можливостей комбінованого застосування ентеросорбції та препаратів гемостимулюючих цитокінів при проведенні протипухлинної хіміотерапії.

КлючОВІ словА: мелфалан; гранулоцитарний колонієстимулюючий фактор, ентеросорбція, структура печінки.

Вступ. Медикаментозне ураження печінки на тлі проведення курсів інтенсивної поліхіміотерапії злоякісних новоутворів трапляється доволі часто і становить близько 10 \% від усіх побічних ефектів, які розвиваються [1]. Пошкодження печінки може призводити до гострої печінкової недостатності та становити загрозу для життя пацієнта $[2,3]$. Відомо, що процеси першого етапу біотрансформації лікарських засобів відбуваються у печінці, окрім того, імуносупресія, яка розвивається на тлі агресивного протипухлинного лікування, також сприяє поглибленню ураження $[1,4]$.

Ступінь інтенсивності розвитку побічних реакцій варіює від 0 (коли відсутні зміни у самопочутті хворого чи зсуви у лабораторних даних) до 3 (різкі порушення, що потребують активного симптоматичного лікування, відтерміновування або припинення хіміотерапії) та 4 ступеня - небезпечне для життя та потребує негайного припинення хіміотерапії $[1,5]$.

Ентеросорбція здавна застосовується для зменшення токсичних навантажень при тривалому застосуванні хіміотерапевтичних лікарських засобів, в тому числі антибактеріальних, протитуберкульозних, антиретровіруснихта антинеопластичних [6-8].

При ризику розвитку фебрильної нейтропенії $>20$ \% на тлі протипухлинної хіміотерапії препарати гранулоцитарного колонієстимулюючого фактора (Г-КСФ) та гранулоцитарно-макрофагального колонієстимулюючого фактора показані для запобігання розвитку ускладнення, а не лише для лікування $[9,10]$.

Враховуючи те, що печінка безпосередньо залучена до процесів метаболізму, метою нашо- го дослідження стало вивчення ії структурних змін при застосуванні мелфалану та препаратів Г-КСФ і ентеросорбції.

Матеріал і методи дослідження. Робота $\epsilon$ частиною НДР 0116 U004148 «Фармакологічні та фармакогенетичні аспекти протекторного впливу імунобіологічних препаратів, ентеросорбентів, речовин природного та синтетичного походження за різних патологічних станів». Гістологічне дослідження на кафедрі патологічної анатомії з секційним курсом та судовою медициною ТНМУ імені І. Я. Горбачевського проводила доцент Т. В. Дацко.

Дослідження проводили на нелійних щурахсамцях масою (200 \pm 20$)$ г, яких утримували на стандартному раціоні віварію. Ми застосовували мелфалан (L-PAM, Алкеран, GlaxoSmithKline), два препарати гранулоцитарного кролонієстимулюючого фактора (Г-КСФ) (розробку IEПОР - біосиміляр Г-КСФ рекомбінантний гранулоцитарний колонієстимулюючий фактор (рГ-КСФ) та філграстим (Нейпоген, Hoffman-La Roche Ltd, Switzerland)). Для ентеральної сорбційної терапії використали вуглецевий гранульований ентеросорбент С2 (насипна

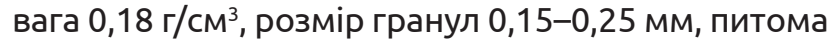
площа поверхні $\left.\mathrm{S}_{\text {вет}}=2162 \mathrm{M}^{2} / \Gamma\right)$. Щури були поділені на групи: 1 група - контрольна; 2 група - щури, яким вводили мелфалан (L-PAM); 3 група - тварини, які отримували мелфалан та ентеральну сорбційну терапію (L-PAM + C2); 4 група - щури, які окрім L-PAM отримували філграстим (L-PAM + філграстим); 5 група щурів, які отримували L-PAM та рекомбінантний Г-КСФ (L-PAM + рГ-КСФ); 6 група філграстим та ентеросорбент С2. Мелфалан вводили внутрішньовенно у хвостову вену з роз- 
Огляди літератури, оригінальні дослідження, погляд на проблему, випадок з практики, короткі повідомлення рахунку 4 мг/кг один раз. Доза препаратів Г-КСФ 50 мкг/кг. Цитокіни вводили підшкірно впродовж 4 днів один раз на добу з наступного дня після введення цитостатика. Інтактні тварини отримували еквівалентну кількість фізіологічного розчину. Сорбент за допомогою зонда вводили у шлунок (завись у дистильованій воді) протягом трьох днів до введення мелфалану та сім днів після цього в дозі 5 мл на 1000 г маси щура (900 мг/кг сухої ваги).

Усі маніпуляції проводили з дотриманням принципів біоетики відповідно до положення Європейської конвенції про захист хребетних тварин, що використовуються для дослідних та інших наукових цілей (European convention for the ргоtection of vertebrate animals used for experimental and other scientific purposes) (Страсбург, 1986), Закону України «Про захист тварин від жорстокого поводження» (№ 1759-VI від 15.12.2009) та Директиви Європейського Союзу 2010/10/63 EU щодо експериментів на тваринах.

На 8-му добу після ін'єкції цитостатика, дотримуючись правил біоетики щодо поводження 3 піддослідними тваринами, за умов евтаназії під кетаміновим знеболюванням для гістологічного дослідження було взято тканини печінки. Кусочки органів фіксували в 10 \% нейтральному розчині формаліну та фіксаторі Ліллі, з наступною заливкою в парафін. Отримані на санному мікротомі зрізи фарбували гематоксиліном та еозином за загальноприйнятою методикою [11]. Послідовність розвитку патологічного процесу документували за допомогою мікроскопа Delta Optical та системи виведення зображень гістологічних препаратів SCMOS Digital Camera і програмного забезпечення Toup View за різного збільшення.

Результати й обговорення. Структура тканин печінки у щура з контрольної групи зображена на рисунку 1.

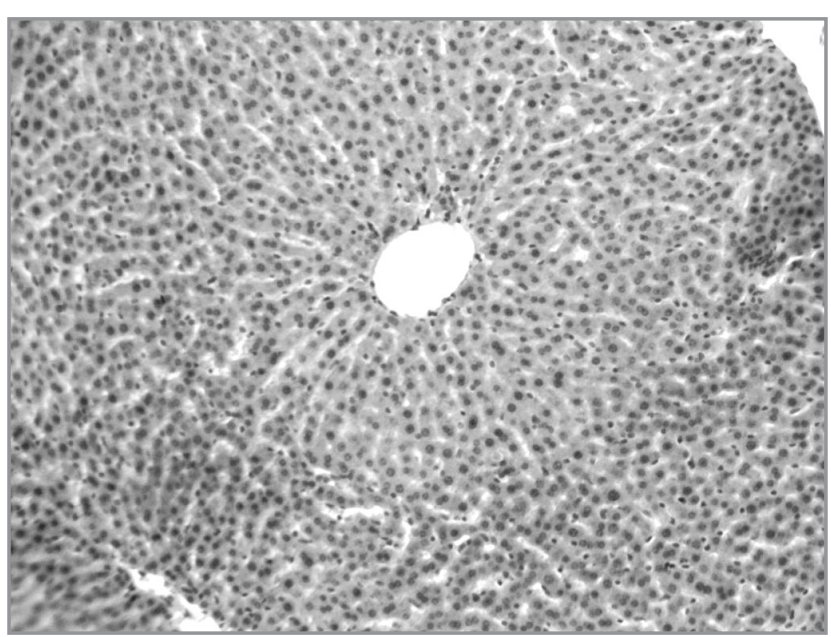

Рис. 1. Структура печінки контрольної тварини. Забарвлення гематоксиліном та еозином. × 100.
При гістологічному дослідженні печінки тварин, котрі отримували мелфалан в дозі 4 мг/кг (рис. 2), встановлено, що структура печінкової часточки була частково збережена. Центральні вени розширювались та містили велику кількість еритроцитів, як і синусоїди, які візуалізувались центролобулярно. Балкова організація гепатоцитів була порушена. В окремих клітинах на фоні деструктивних змін цитоплазми ядра були із ознаками каріопікнозу та каріолізису, що свідчить про наявність дистрофічно-некротичних проявів. Портальні тракти розширювались в основному за рахунок незначного розширення й повнокров'я судин та незначного розширення жовчних проток. Жовчні пігменти у їх просвітах були відсутні. Спостерігалася помірна лімфо-гістіоцитарна інфільтрація.

У тварин, які в якості коригуючого чинника отримували курс ентеросорбції з С2 (рис. 3), при гістологічному дослідженні тканини печінки виявлено, що структура печінкової часточки покращувалась. Центральні вени були менш розширеними та містили незначну кількість еритроцитів. Синусоїди містили поодинокі еритроцити та макрофаги. Балкова організація гепатоцитів була збереженою переважно в центролобулярних зонах. Цитоплазма клітин центролобулярної зони, середньої третини часточки та перипортальних полів була дрібнозернистою, місцями просвітленою. Переважна більшість гепатоцитів містили ядра. В периваскулярних просторах виявляли поодинокі лімфогістіоцити.

При гістологічному дослідженні тканини печінки тварин, які отримували р-ГКСФ (рис. 4) та філграстим (рис. 5), встановлено, що у обох випадках структура печінкової часточки була збережена частково.

При застосуванні філграстиму центральні вени добре візуалізувались, дещо розширювались, містили незначну кількість еритроцитів. Синусоїди добре контурувались лише в окремих полях зору, містили поодинокі еритроцити та макрофаги. Балкова організація гепатоцитів була збереженою переважно в центролобулярних зонах. Цитоплазма клітин як центролобулярної зони, середньої третини часточки та перипортальних полів була дрібнозернистою, місцями просвітленою. Переважна більшість гепатоцитів містили великі гіперхромні ядра. Портальні тракти розширювались в основному за рахунок незначного розширення та повнокров'я судин. Жовчні протоки не візуалізувались, холестазів не виявлено. В периваскулярних просторах виявлялись поодинокі лімфогістіоцити.

При застосуванні р-ГКСФ (рис. 4) у тканині печінки центральні вени добре візуалізувались, 
Огляди літератури, оригінальні дослідження, погляд на проблему, випадок з практики, короткі повідомлення

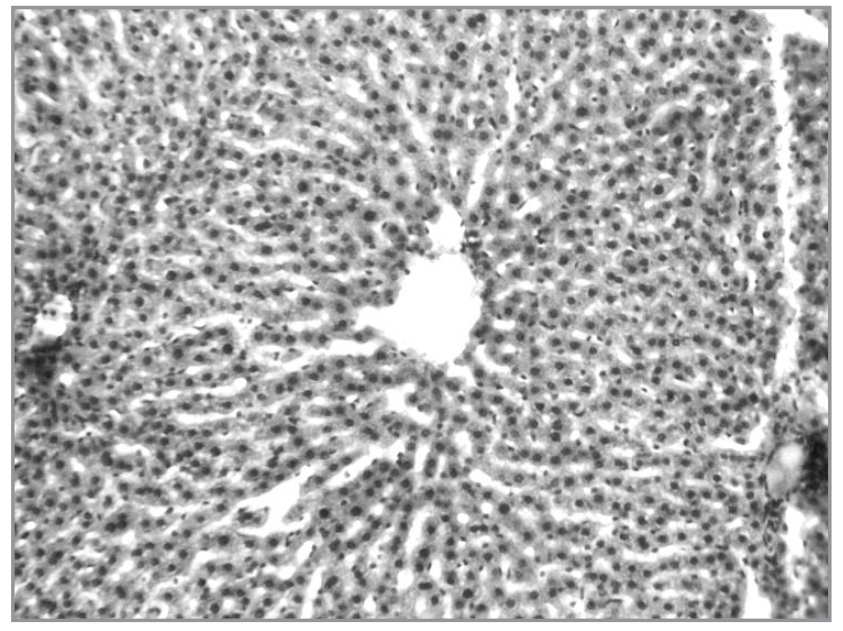

Рис. 2. Структура печінки дослідної тварини, яка отримувала мелфалан у дозі 4 мг/кг одноразово. Забарвлення гематоксиліном та еозином. × 100.

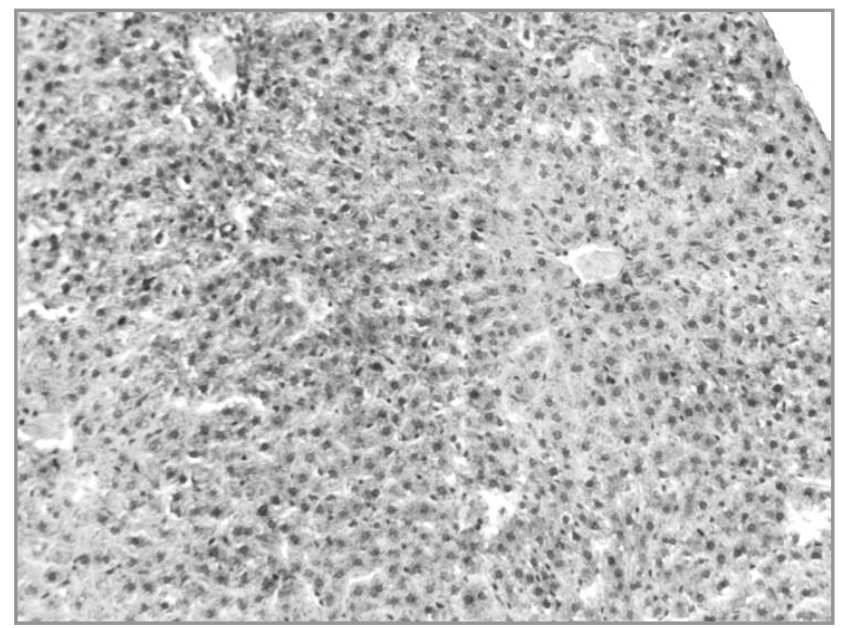

Рис. 4. Структура печінки дослідної тварини з групи L-PAM4+p-ГКСФ. Забарвлення гематоксиліном та еозином. × 100 .

дещо розширювались, мали нерівномірне кровонаповнення. Синусоїди контурувались лише в окремих полях зору, містили поодинокі еритроцити та макрофаги. Балкова організація гепатоцитів була збереженою переважно в центролобулярних зонах. Цитоплазма клітин центролобулярної зони, середньої третиничасточки та перипортальних полів була дрібнозернистою, місцями просвітленою. Ядра окремих клітин були зміненими. Мали місце поодинокі внутрішньоклітинні холестази.

Однак максимальне покращення структури печінки спостерігалось при поєднаному застосуванні обох чинників - і ентеросорбента С2, і філграстиму (рис. 6).

Гістологічно структура печінкової часточки була збереженою. Центральні вени та синусоїди добре візуалізувались, містили незначну кількість еритроцитів, поодинокі макрофаги. Балкова

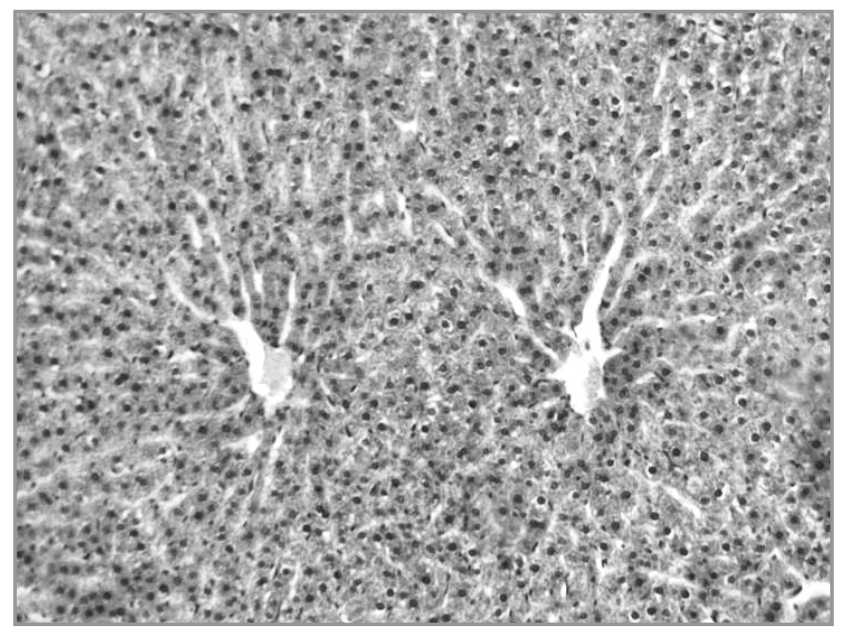

Рис. 3. Структура печінки дослідної тварини з групи L-PAM+C2. Забарвлення гематоксиліном та еозиHом. $\times 100$.

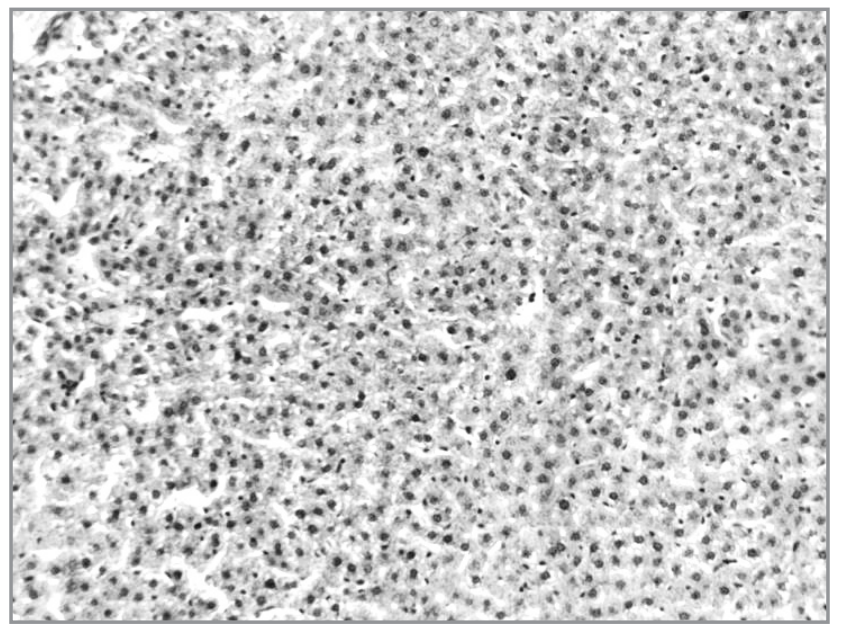

Рис. 5. Структура печінки дослідної тварини 3 групи L-PAM+філграстим. Забарвлення гематоксиліном та еозином. × 100.

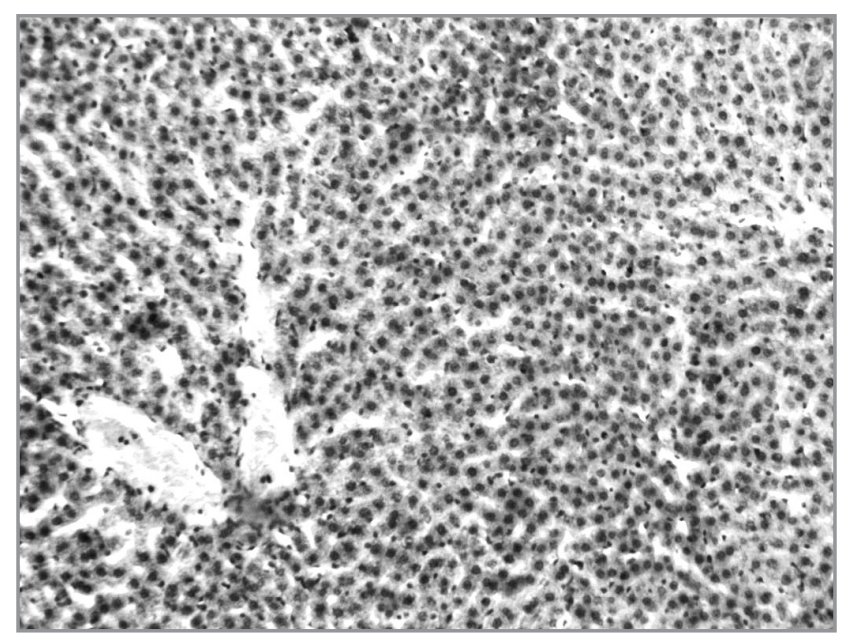

Рис. 6. Структура печінки дослідної тварини з групи L-PAM + філграстим + C2. Забарвлення гематоксиліном та еозином. $\times 100$. 
Огляди літератури, оригінальні дослідження, погляд на проблему, випадок з практики, короткі повідомлення організація гепатоцитів була збереженою. Контури клітин та міжклітинні зв'язки були збереженими. Переважна більшість гепатоцитів містили гіперхромні ядра, що свідчить про активацію процесів регенерації. Портальні тракти розширювались в основному за рахунок незначного розширення та повнокров'я судин. Жовчні протоки не візуалізувались, холестазів не спостерігалось. У периваскулярних просторах виявлялись поодинокі лімфогістіоцити.

Дослідження біохімічних маркетів гепатотоксичності, активності АсАТ та АлАТ, показало, що у дозі 4 мг/кг мелфалан викликав зростання активності лише АлАТ на 61,9 \%, однак змін з боку інших показників цитолізу і холестазу відмічено не було [12].

Отримані нами дані узгоджуються з результатами інших дослідників [1, 13], та свідчать про те, що мелфалан викликає транзиторне ураження печінки. Однак, необхідно враховувати те, що ми проводили дослідження на здорових тваринах,

без перевивних пухлин. Отримані морфологічні дані узгоджуються з попередніми результатами біохімічних показників, отриманими нами $[12,14]$.

Висновки. Мелфалан при одноразовому внутрішньовенному введенні у дозі 4 мг/кг викликає порушення структури печінки. Комбіноване введення ентеросорбента С2 у поєднанні з гранулоцитарним колонієстимулюючим фактором (філграстимом) для корекції поліпатичних проявів та явищ, які виникають при введенні алкілуючого цитостатика мелфалану, переважає за ефективністю монозастосування кожного середника. Вітчизняна версія р-КСФГ за своєю експериментально-лікувальною дією не поступається офіцинальному препарату.

Перспективи подальших досліджень. Отримані нами результати слугують основою для подальшого вивчення можливостей комбінованого застосування ентеросорбції та препаратів гемостимулюючих цитокінів при проведенні протипухлинної хіміотерапії.

\section{ЛІТЕРАТУРА}

1. Токсичне ураження печінки у пацієнтів з онкологічною патологією (діагностика, лікування) / О. А. Карнабеда, С. М. Ткач, В. Г. Передерій [та ін.] // Клиническая онкология. - 2013. - № 9. - С. 125-131.

2. Reuben A. Drug-induced acute liver failure: Results of a U.S. multicenter, prospective study / A. Reuben, D. G. Koch, W. M. Lee // Hepatology. - 2010. - No. 52. P. 2065-2076.

3. $\mathrm{CSH}$ guidelines for the diagnosis and treatment of drug-induced liver injury / Y. C. Yu, Y. M. Mao, C. W. Chen [et al.] // Hepatology International. - 2017. - No. 11. P. 221-241.

4. Drug-induced bile duct injury / M. Visentin, D. Lenggenhager, Z. Gai [et al.] // Biochimica et Biophysica Acta-Molecular Basis of Disease. - 2018. - No. 1864. P. 1498-1506.

5. Борисенко $€$. О. Токсичне ураження печінки, індуковане хіміотерапією у пацієнтів із гострими лейкозами / Є. О. Борисенко // Семейная медицина. - 2016. № 67. - С. 161-164.

6. Вивчення можливостей корекції гепатотоксичної дії антиретровірусних засобів за допомогою ентеросорбенту ентеросгель - паста для перорального застосування / К. А. Посохова, В. Г. НіколаєВ, О. О. Шевчук [та ін.] // Актуальні проблеми сучасної медицини. Вісник Української медичної стоматологічної академії. - 2010. № 10. - C. 121-125.

7. The influence of antiretroviral and antituberculosis agents on the biochemical and histopathological indices of liver function in rats / O. O. Shevchuk, K. A. Posokhova, O. M. Oleshchuk [et al.] // Int. J. Med. Res. - 2015. - No. 1. P. 68-74.

8. Корекція гепатотоксичної дії антиретровірусних засобів за допомогою ентеросорбенту Ентеросгель / К. А. Посохова, В. Г. Ніколаєв, О. О. Шевчук [та ін.] // Мистецтво лікування. - 2011. - № 79. - С. 81-83.

9. Mehta H. M. G-CSF and GM-CSF in neutropenia // H. M. Mehta, M. Malandra, S. J. Corey // J. Immunol. - 2015. No. 195. - P. 1341-1349.

10. The impact of concurrent granulocyte-macrophage colony-stimulating factor on quality of life in head and neck cancer patients: Results of the randomized, placebocontrolled Radiation Therapy Oncology Group 9901 trial / K. E. Hoffman, S. L. Pugh, J. L. James [et al.] // Qual. Life Res. - 2014. - No. 23. - P. 1841-1858.

11. Горальський Л. П. Основи гістологічної техніки і морфофункціональні методи досліджень у нормі та при патології : навч. посіб. / Л. П. Горальський, В. Т. Хомич, О. І. Кононський ; за ред. Л. П. Горальського. - Вид. 3-є, випр. і допов. - Житомир : Полісся, 2015. - 286 с.

12. Enterosorption combined with granulocyte colony stimulating factor decreases melphalan gonadal toxicity / O. O. Shevchuk, Y. Y. Bodnar, K. I. Bardakhivska [et al.] // Exp. Oncol. - 2016. - No. 38. - P. 172-175.

13. Недашківський С. М. Медикаментозно зумовлені ураження печінки: принципи діагностики, патологічні зміни й підходи до лікування / С. М. Недашківський // Медицина невідкладних станів. - 2019. - № 97. C. 63-70.

14. The influence of enterosorption on some haematological and biochemical indices of the normal rats after single injection of melphalan / O. O. Shevchuk, K. A. Posokhova, A. S. Sidorenko [et al.] // Exp. Oncol. - 2014. - No. 36. P. 94-100. 
Огляди літератури, оригінальні дослідження, погляд на проблему, випадок з практики, короткі повідомлення REFERENCES

1. Karnabeda, O.A., Tkach, S.M., Perederii, V.H. \& Chichula, Yu.V. (2013). Toksychne urazhennia pechinky u patsiientiv z onkolohichnoiu patolohiieiu (diahnostyka, likuvannia) [Toxic liver injury in oncological patients (diagnosis and treatment)]. Klinicheskaya onkologiya - Clinical Oncology, 9 (1), 125-131. Retrieved from: https://www. clinicaloncology.com.ua/article/7342/toksichneurazhennya-pechinki-u-paciyentiv-z-onkologichnoyupatologiyeyu-diagnostika-likuvannya [in Ukrainian].

2. Reuben, A., Koch, D.G., \& Lee, W.M. (2010). Drug-induced acute liver failure: Results of a U.S. multicenter, prospective study. Hepatology, 52 (6), 2065-2076. Retrieved from: https://doi.org/10.1002/hep.23937

3. Yu, Y.C., Mao, Y.M., Chen, C.W., Chen, J.J., Chen, J., Cong, W.M., ..., \& Zhuang, H. (2017). CSH guidelines for the diagnosis and treatment of drug-induced liver injury. Hepatol. Int., 11 (3), 221-241.

4. Visentin, M., Lenggenhager, D., Gai, Z., Kullak-Ublick, G.A. (2018). Drug-induced bile duct injury. Biochim. Biophys. Acta Mol Basis Dis., 1864 (4, Pt. B), 1498-1506. Retrieved from: https://doi.org/10.1016/j.bbadis.2017.08.033

5. Borysenko, E.O. (2016). Toksychne urazhennia pechinky, indukovane khimioterapiieiu u patsiientiv iz hostrymy leikozamy [Toxic liver injury induces by chemotherapy in patients with acute leukoses]. Semeynaya MeditsinaFamily Medicine, 67 (5), 161-164 [in Ukrainian].

6. Posokhova, K.A., Nikolaev, V.G., Shevchuk, O.O., Oleshchuk, O.M., Klishch, I.M., \& Nikolaeva, V.V. (2010). Vyvchennia mozhlyvostei korektsii hepatotoksychnoi dii antyretrovirusnykh zasobiv za dopomohoiu enterosorbentu enteroshel - pasta dlia peroralnoho zastosuvannia [Study of capability to diminish hepatotoxic action of antiretroviral drugs with enterosorbent Enterosgel - perooral paste]. Aktualni problemy suchasnoi medytsyny. Visnyk Ukrainskoi medychnoi stomatolohichnoi akademii - Actual problems of moderm medicine. Bulletin of Ukrainian medical stomatological academy, 0 (4), 121-125. [in Ukrainian].

7. Shevchuk, O.O., Posokhova, K.A., Oleshchuk, O.M., \& Datsko, T.V. (2015). The influence of antiretroviral and antituberculosis agents on the biochemical and histopathological indices of liver function in rats. International Journal of Medicine and Medical Research, 1 (1), 68-74. Retrieved from: https://doi.org/10.11603/ijmmr.2413-6077. 2015.1.2821
8. Posokhova, K.A., Nikolaev, V.G., Shevchuk, O.O., Oleshchuk, O.M., \& Klishch, I.M. (2011). Korektsiia hepatotoksychnoii diii antyretrovirusnykh zasobiv za dopomohoiv enterosorbentu Enteroshel [Correction of hepatotoxic effects of antiretroviral drugs by enterosorbent Enterosgel]. Mystetstvo Likuvannia - The Art of Treatment, 79 (3), 81-83. Retrieved from: www.health-medix.com [in Ukrainian].

9. Mehta, H.M., Malandra, M., \& Corey, S.J. (2015). G-CSF and GM-CSF in Neutropenia. The Journal of Immunology, 195(4), 1341-1349. Retrieved from: https:// doi.org/10.4049/jimmunol.1500861

10. Hoffman, K.E., Pugh, S.L., James, J.L., Scarantino, C., Movsas, B., Valicenti, R. K., ..., \& Kachnic, L.A. (2014). The impact of concurrent granulocyte-macrophage colonystimulating factor on quality of life in head and neck cancer patients: Results of the randomized, placebo-controlled Radiation Therapy Oncology Group 9901 trial. Quality of Life Research, 23 (6), 1841-1858. Retrieved from: https:// doi.org/10.1007/s11136-014-0628-5

11. Horalskyi, L., Khomych, V., \& Kononskyi, O. (2015). Osnovy histolohichnoi tekhniky i morfofunktsionalni metody doslidzhen u normi ta pry patolohii: navch. posib [Histological techniques and methods of morphological studies in normal and pathological conditions: textbook]. Horalskyi L.P. (ed.). Zhytomyr: Polissia. Retrieved from: http:// ir.znau.edu.ua/handle/123456789/3788 [in Ukrainian].

12. Shevchuk, O.O., Bodnar, Y.Y., Bardakhivska, K.I., Datsko, T.V., Volska, A.S., Posokhova, K.A., ..., \& Nikolaev, V.G. (2016). Enterosorption combined with granulocyte colony stimulating factor decreases melphalan gonadal toxicity. Experimental Oncology, 38 (3), 172-175.

13. Nedashkivskyi, S.M. (2019). Medykamentozno zumovleni urazhennia pechinky: pryntsypy diahnostyky, patolohichni zminy i pidkhody do likuvannia [Drug-induced liver injury: principles of diagnosis, pathological changes and treatment]. Medytsyna nevidkladnykh staniv-Emergency Medicine, 97 (1), 63-70 [in Ukrainian].

14. Shevchuk, O.O., Posokhova, K.A., Sidorenko, A.S., Bardakhivska, K.I., Maslenny, V.M., Yushko, L.A., ..., \& Nikolaev, V.G. (2014). The influence of enterosorption on some haematological and biochemical indices of the normal rats after single injection of melphalan. Experimental Oncology, 36 (2), 94-100.

\section{СТРУКТУРНАЯ РЕОРГАНИЗАЦИЯ ПЕЧЕНИ, ВЫЗВАННАЯ МЕЛФАЛАНОМ, И ПРИ КОРРЕКЦИИ ПРЕПАРАТАМИ ГРАНУЛОЦИТАРНОГО КОЛОНИЕСТИМУЛИРУЮЩЕГО ФАКТОРА И ЭНТЕРОСОРБЦИЕЙ}

๑О. О. Шевчук

\section{Тернопольский национальный медицинский университет имени И. Я. Горбачевского Мз Украины}

РЕзЮМЕ. Цель работы - изучить структурные изменения тканей печени при применении мелфалана, гранулоцитарного колониестимулирующего фактора (Г-КСФ) и энтеросорбции.

Материал и методы. Проведено гистологическое исследование структурной реорганизации ткани печени в эксперименте на 60 половозрелых белых крысах при применении мелфалана, филграстима, рГ-КСФ, и энте-

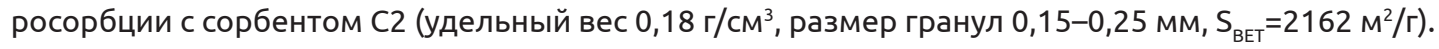


Огляди літератури, оригінальні дослідження, погляд на проблему, випадок з практики, короткі повідомлення

Результаты. Установлено, что только при комбинировании гранулоцитарного колониестимулирующего фактора и курса энтеральной сорбционной терапии наблюдалось максимальное восстановление гистоструктуры печени, которая нарушается при введении цитостатика мелфалана.

Выводы. Полученные нами результаты служат основой для дальнейшего исследования возможностей использования изучаемой комбинации препаратов гранулоцитарного колониестимулирующего фактора (Г-КСФ) и энтеросорбции при проведении противоопухолевой химиотерапии.

КЛЮЧЕВЫЕ СЛОВА: мелфалан; гранулоцитарный колониестимулирующий фактор; энтеросорбция; структура печени.

\section{LIVER STRUCTURE'S REORGANIZATION, INDUCED BY MELPHALAN, AND ITS CORRECTION WITH GRANULOCYTE COLONY STIMULATING FACTOR AND ENTEROSORPTION}

๑O. O. Shevchuk

\section{Horbachevsky Ternopil National Medical University}

SUMMARY. The aim of the work - to study structural changes of liver tissues in melphalan, granulocyte colony stimulating factor (G-CSF) biosimilars and enterosorption use.

Material and Methods. Histological examination of rats' liver tissues was performed in melphalan, granulocyte colony stimulating factor and enterosorption use.

Results. It was proved that combination of granulocyte colony stimulating factor and enteral sorption therapy was the most efficient to improve the liver structure, which is disrupted because of melphalan injection.

Conclusions. Proved protective effects on the liver structure are the ground for further investigation of therapeutic capability of combination of granulocyte colony stimulating factor and enterosorption in anti-cancer chemotherapy.

KEY WORDS: melphalan; granulocyte colony stimulating factor; enterosorption; kidney structure.

Отримано 29.11.2019 